\title{
Evidence Based Chest Physiotherapy for Cystic Fibrosis
}

\author{
Mohammad Habibur Rahman* \\ Lecturer (Physiotherapy), School of Science and Technology, Bangladesh Open University, Gazipur-1705, Bangladesh
}

*Corresponding author: Mohammad Habibur Rahman, Lecturer (Physiotherapy), School of Science and Technology, Bangladesh

Open University, Gazipur-1705, Bangladesh

\section{ARTICLE INFO}

Received: 㓞 February 14, 2019

Published: 慧 February 27, 2019

Citation: Mohammad Habibur Rahman. Evidence Based Chest Physiotherapy for Cystic Fibrosis. Biomed J Sci \& Tech Res 15(2)-2019. BJSTR. MS.ID.002673.

\section{ABSTRACT}

Cystic fibrosis (CF) is a genetically predisposed disease causing difficulties in clearance of bronchial sections. In addition to medicine different physiotherapy treatment techniques for instance postural drainage, percussion, chest shaking, huffing and coughing helps to clear bronchial sections and lessen the work of breathing. Absolute indication and dose based chest physiotherapy is mandatory and evidence based physiotherapy practice is essential for livelihood of a CF patient.

Abbreviations: CF: Cystic Fibrosis; PEP: Positive Expiratory Pressure; HPEP: High pressure PEP; P\&PD: Percussion and Postural Drainage; OPEP: Oscillatory PEP; HFCC: High Frequency Chest Compressions; AD: Autogenic Drainage.

\section{Introduction}

Pulmonary diseases regarded as one of the main sources of limitation in daily livelihood. These limitations are highly influenced by difficulties to clear bronchial secretions, symptoms of breathlessness and decrease exercise tolerance [1]. Chest disease like cystic fibrosis (CF) exhibited similar features described as earlier. However, $\mathrm{CF}$ is associated with morbidity and an infrequent threat of life [2]. CF is a genetic disease characterized by dehydration of airway surface liquid and causing difficulties of mucociliary clearance. As a result patients experience chronic pulmonary infections as well as inflammation.

\section{Methods}

Sixty experimental and quasi experimental studies were found using PUBMED, GOOGLE SCHOLAR, CINAHL and HINARI in which eight were cross over studies focusing on chest physiotherapy techniques. Among those one investigated the effects of autogenic drainage, six focused on conventional chest physiotherapy, three applied oscillating positive expiratory pressure, seven investigated the effects of positive expiratory pressure and another one examined the effects of high pressure positive expiratory pressure on respiratory functions.
Among the eight crosses over studies, six experiments focused on single treatment approaches in which four experiments comprising of 28 participants was found a huge amount of expelled secretions after application of chest physiotherapy when compared to no treatment option. One experiment was conducted on 18 participants and found similarities of sputum weight when compared to control group. However, another one study found that chest physiotherapy for $\mathrm{CF}$ was solely based on airway clearance techniques and these were Positive Expiratory Pressure (PEP) mask therapy, High pressure PEP (HPEP) mask therapy, ACBT, autogenic drainage, exercise and oscillating devices. Four reviews addressed Percussion and Postural Drainage (P\&PD), two reviews addressed Positive Expiratory Pressure (PEP) and two addressed physical training. Among the nineteen additional controlled trials, five studies assessed P\&PD, two PEP, four Oscillatory PEP (OPEP), six assessed High Frequency Chest Compressions (HFCC), three physical or exercise training, three ACBT and no additional studies were identified addressing high pressure PEP (HPEP) or Autogenic Drainage (AD).

Discussion: (Table: 1) [3-11] 
Table 1.

\begin{tabular}{|c|c|c|c|}
\hline $\begin{array}{l}\text { Airway Clearance Tech- } \\
\text { nique }\end{array}$ & Study Design & Interventions & Applicable Age Range \\
\hline \multirow[t]{2}{*}{$\begin{array}{l}\text { Conventional chest phys- } \\
\text { iotherapy } \\
{[3,4]}\end{array}$} & $\begin{array}{l}\text { Systematic } \\
\text { review }\end{array}$ & $\begin{array}{l}\text { Postural drainage, components of the ACBT, huffing, percussion, } \\
\text { shaking, and vibrations }\end{array}$ & $\geq 18$ months \\
\hline & $\begin{array}{l}\text { Systematic } \\
\text { review }\end{array}$ & $\begin{array}{l}\text { Postural drainage, percussion, chest shaking, huffing and directed coughing. It } \\
\text { did not include the use of exercise, FET, PEP or other mechanical devices. }\end{array}$ & $\geq 2$ years \\
\hline \multirow{2}{*}{ ACBT $[5,6]$} & $\begin{array}{l}\text { Systematic } \\
\text { review }\end{array}$ & $\begin{array}{l}\text { Breathing control with thoracic expansion and the forced expiration tech- } \\
\text { nique (FET). It may also include postural drainage and chest clapping. }\end{array}$ & $\geq 4$ years \\
\hline & RCT & $\begin{array}{l}\text { ACBT comprising breathing control, thoracic expansion exercises and the FET, } \\
\text { frequently combined with gravity assisted positioning. }\end{array}$ & $\geq 4$ years \\
\hline Autogenic Drainage [7] & RCT & $\begin{array}{l}\text { Low lung volume to unstuck mucus in peripheral airways, mid-lung volume } \\
\text { to collect mucus in middle airways and high lung volumes to expel mucus } \\
\text { from central airways. }\end{array}$ & $\geq 8$ years \\
\hline $\begin{array}{l}\text { Airway Oscillating Devices } \\
\text { (AOD) [8] }\end{array}$ & RCT & $\begin{array}{l}\text { Delivered oscillatory positive pressure during expiration by pipe shaped } \\
\text { hand-held device. }\end{array}$ & $\geq 4$ years \\
\hline $\begin{array}{l}\text { Percussion and Postural } \\
\text { Drainage [9] }\end{array}$ & RCT & $\begin{array}{l}\text { Postural drainage: Different drainage position based on affected lobe } \\
\qquad \text { versus } \\
\text { PEP-mask: Delivering positive pressure }\end{array}$ & All ages \\
\hline $\begin{array}{l}\text { Positive Expiratory Pres- } \\
\text { sure (PEP) [10] }\end{array}$ & RCT & $\begin{array}{l}\text { High-Frequency Chest Compression (HFCC): oscillation with frequency be- } \\
\text { tween } 5 \text { and } 15 \mathrm{HZ} \text { by compressive jacket generates airways vibrations, } \\
\text { Positive Expiratory Pressure: Delivering a positive pressure between } 10-20 \\
\qquad \mathrm{~cm} \mathrm{H}_{2} \mathrm{O} \text { via a facemask or mouthpiece. }\end{array}$ & $\geq 4$ years \\
\hline Exercise [11] & RCT & $\begin{array}{l}\text { Aerobic exercise: Aerobic exercise program (walking and running) three days } \\
\text { a week for three weeks at } 70 \% \text { of the maximum heart rate showed increase in } \\
\text { respiratory muscle endurance and improvement in aerobic performance. }\end{array}$ & $\geq 8$ years \\
\hline
\end{tabular}

\section{Conclusion}

CF is a disabling condition causing impairments in lung function. The huge production of sections and symptoms of breathlessness is an emergency. This short communication found that evidence based chest physiotherapy techniques helped to clear secretion and provided eases in breathing.Thus a person with CF can maintain better quality of life through application of evidence based and appropriately indicated chest physiotherapy

\section{References}

1. Lechtzin N, West N, Allgood S, Wilhelm E, Khan U, et al. (2013) Rationale and Design of a Randomized Trial of Home Electronic Symptom and Lung Function Monitoring to Detect Cystic Fibrosis Pulmonary Exacerbations: the early intervention in cystic fibrosis exacerbation Trial. Contemp Clin Trials 36(2): 460-469.

2. Flume PA, Van Devanter DR (2012) State of progress in treating cystic fibrosis respiratory disease. BMC Med 10(88): 2-3.

3. Daniels T (2013) Physiotherapeutic management strategies for the treatment of cystic fibrosis in adults. J Multidiscip Healthc 3: 201-212.

4. Main E, Prasad A, Van der Schans CP (2005) Conventional chest physiotherapy compared to other airway clearance techniques for cystic fibrosis. Coch Database Syst Reviews 25(1): CD002011.
5. McKoy NA, Saldanha IJ, Odelola OA, Robinson KA (2012) Active cycle of breathing technique for cystic fibrosis. Coch Database Syst Reviews 12: CD007862.

6. Prasad SA, Tannenbaum E, Mikelsons C (2005) Physiotherapy in cystic fibrosis. JRSM 93(Suppl. 38): 27-36.

7. Pryor JA, Tannenbaum E, Cramer D, Scott SF, Burgess J, et al. (2006) A comparison of five airway clearance techniques in the treatment of people with cystic fibrosis. J Cys Fib 5: 76.

8. Mcllwaine PM, Wong LT, Peacock D, Davidson AGF (2005) Long-term comparative trial of positive expiratory pressure versus oscillating positive expiratory pressure (flutter) physiotherapy in the treatment of cystic fibrosis. J Pedi 138(6): 845-850.

9. Costantini D, Brivio A, Brusa D, Delfino R, Fredella C, et al. (2005) PEPmask versus postural drainage in $\mathrm{CF}$ infants a long-term comparative trial. Pedi Pulmonol Suppl 22: 308.

10. Fainardi V, Longoa F, Faverzani S, Tripodi MC, Chettab A, et al. (2011) Short-Term Effects of High-Frequency Chest Compression and Positive Expiratory Pressure in Patients with Cystic Fibrosis. J Clin Med Res 3(6): 279-284.

11. Elbasan B, Tunali N, Duzgun I, Ozcelik U (2012) Effects of chest physiotherapy and aerobic exercise training on physical fitness in young children with cystic fibrosis. Ital J Pediatr 38: 2 . 


\section{ISSN: 2574-1241}

DOI: 10.26717/BJSTR.2019.15.002673

Mohammad Habibur Rahman. Biomed J Sci \& Tech Res

cC) (i) This work is licensed under Creative

Submission Link: https://biomedres.us/submit-manuscript.php

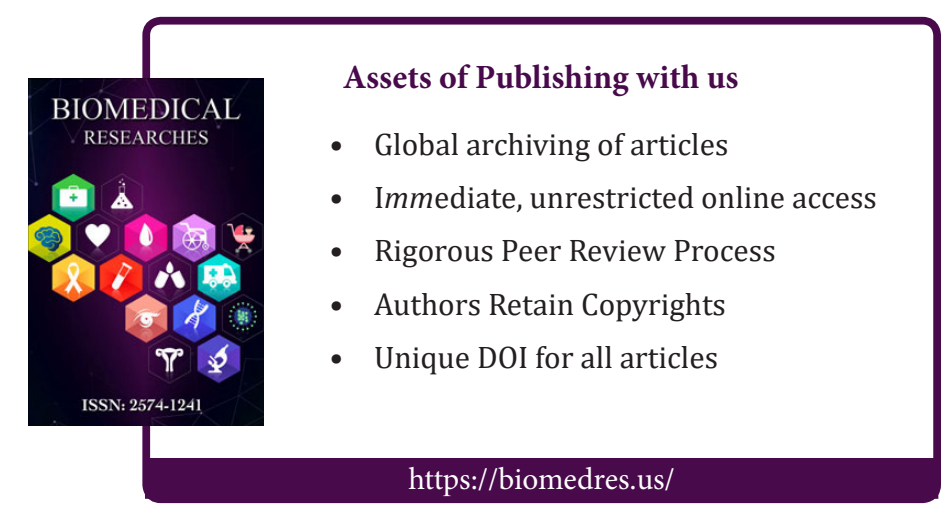

